\title{
Combined clonidine-short-ACTH test for the simultaneous assessment of growth hormone reserve and hypothalamic- pituitary-adrenal axis integrity in children
}

\author{
Naomi Weintrob ${ }^{1,2}$, Elliot Sprecher ${ }^{1}$, Zeev Josefsberg ${ }^{1,2}$, Pnina Vardi $^{1,2}$, Clara Weininger $^{1}$, \\ Yaffa Aurbach-Klipper ${ }^{1,2}$, Athalia Pertzelan ${ }^{1,2}$ and Moshe Phillip ${ }^{1,2}$ \\ ${ }^{1}$ Institute for Endocrinology and Diabetes, Schneider Children's Medical Center of Israel, Petah Tiqva, and ${ }^{2}$ Sackler Faculty of Medicine, \\ Tel Aviv University, Tel Aviv, Israel \\ (Correspondence should be addressed to N Weintrob, Institute for Endocrinology and Diabetes, Schneider Children's Medical Center of Israel, \\ 14 Kaplan St, Petah Tiqva 49202, Israel; Fax: +972-3-925-3836)
}

\begin{abstract}
Objective: To determine the feasibility of using the combined oral clonidine and the short-ACTH test instead of the sometimes dangerous insulin-induced hypoglycemia test as a screening procedure, for the simultaneous assessment of growth hormone reserve and hypothalamic-pituitary-adrenal axis integrity in children with growth retardation.

Design: Evaluative study.

Method: Seventy-three children (52 males) aged $11 \pm 3$ years with attenuated growth (group 1) were tested by combined clonidine $\left(150 \mu \mathrm{g} / \mathrm{m}^{2}\right)$ and short-ACTH test (either the standard $250 \mu \mathrm{g}$ or the lowdose $1 \mu \mathrm{g} / 1.73 \mathrm{~m}^{2}$ ). Thirty-one children received no pretreatment (nonprimed) (subgroup $1 \mathrm{NP}$ ), and 42 were primed with ethynylestradiol $40 \mu \mathrm{g} / \mathrm{m}^{2} /$ day two days before testing (subgroup 1P). The control group for the short-ACTH test (group 2) consisted of 42 children and adolescents (13 males) aged $12 \pm 3$ years with early or accelerated puberty or premature closure of epiphyses, who received ACTH only ( 21 standard, 21 low-dose) with no evidence of adrenal or pituitary pathology.

The peak GH response was compared between the primed and the nonprimed group 1 subjects, and the cortisol levels were compared between the combined test subgroups and the controls. The peak pass level for growth hormone was $10 \mathrm{ng} / \mathrm{ml}$; the peak pass level for cortisol was $520 \mathrm{nmol} / \mathrm{l}$.

Results: Sixty-four of the 73 children in group $1(87.7 \%)$ showed a growth hormone level of $\geq 10 \mathrm{ng} / \mathrm{ml}$ on the first stimulation test, including 26/31 (84\%) nonprimed and 38/42 (90.5\%) primed. Of the 9 patients who failed the first clonidine test, 4 also failed the second, primed test, including $1 / 5$ nonprimed patients $(20 \%)$ and $3 / 4$ primed patients $(75 \%)$. This yielded a GH deficiency/ insufficiency rate of 5.5\% and a rather low false-positive rate of $13.3 \%(4 / 30)$ for the nonprimed subjects and 2.6\% (1/39) for the primed subjects. Peak 30-min cortisol in response to ACTH stimulation was similar in the patients who underwent the $250 \mu \mathrm{g}$ or the $1 \mu \mathrm{g}$ test within each group (subgroup 1NP, subgroup $1 \mathrm{P}$ and group 2); therefore, the results for the two tests were considered together. Compared with group 2, subgroup $1 \mathrm{NP}$ patients had a similar 30-min cortisol response $(P=\mathrm{NS})$, and subgroup $1 \mathrm{P}$ patients had a much higher response $(P<0.05)$ (group $2=690 \pm 145 \mathrm{nmol} / \mathrm{l}$, subgroup $1 \mathrm{NP}=772 \pm 195 \mathrm{nmol} / \mathrm{l}$, subgroup $1 \mathrm{P}=934 \pm 209 \mathrm{nmol} / \mathrm{l})$. However, there was no significant difference in the increment in cortisol response between the three groups.

Conclusions: Our results suggest that the combined clonidine-short-ACTH test is a reliable and safe tool for the simultaneous assessment of growth hormone reserve and hypothalamic-pituitaryadrenal axis integrity in children.
\end{abstract}

European Journal of Endocrinology 143 105-110

\section{Introduction}

The efficient diagnostic assessment of growth hormone (GH) secretion is important in children with growth failure, because $\mathrm{GH}$ deficiency is readily treatable. Among the various laboratory methods available, provocative
GH testing is the most useful and reliable (1). Being that $10 \%$ of patients with idiopathic GH deficiency also have adrenocorticotropin (ACTH) deficiency $(2,3)$, clinicians have traditionally used either the insulin-induced hypoglycemia (IIH) test (4) or the glucagon test (5) to assess concomitantly GH reserve and the integrity of the 
hypothalamic-pituitary-adrenal (HPA) axis. These tests, however, involve some risk: death from hypoglycemia or overly vigorous replacement of glucose has been reported (6). Therefore, researchers have been seeking alternatives. The clonidine stimulation test in children, in contradistinction to adults (7), has been shown to be reliable, sensitive, specific, reproducible and safe as an outpatient procedure for the assessment of the GH reserve (8-11). However, clonidine, a central alphaadrenergic agonist, suppresses rather than stimulates the HPA axis $(9,12)$ and therefore cannot serve to measure simultaneously $\mathrm{GH}$ and cortisol secretion. The simple, innocuous 60-min short-ACTH test has been used for years to investigate the HPA axis, but its results do not always correlate with those of the IIH test (13, 14), making its use for the detection of secondary adrenal insufficiency controversial $(15,16)$. Recently, a low-dose $\left(1 \mu \mathrm{g} / 1.73 \mathrm{~m}^{2}\right)$ ACTH test was introduced and found to be more sensitive than the standard $250 \mu \mathrm{g}$ test to assess the integrity of the HPA axis $(17,18)$. In a study by our team, we have found that both the standard and the low-dose short-ACTH stimulation tests are equivalent to the $\mathrm{IIH}$ test in detecting secondary adrenal insufficiency in patients with idiopathic multiple pituitary hormone deficiencies (19). Our results are in agreement with those of other studies of the standard-dose short-ACTH test in patients with suspected hypothalamic-pituitary disorder (15).

The purpose of the present study was to assess the concomitant use of clonidine and the short-ACTH test for the simultaneous assessment of $\mathrm{GH}$ reserve and the integrity of the HPA axis in children with short stature or growth retardation. As estrogen priming substantially decreases the false-positive rate of the $\mathrm{GH}$ stimulation test (20), its effect on $\mathrm{GH}$ and cortisol responses was also studied.

\section{Subjects and methods}

\section{Subjects (Table 1)}

The study population comprised 115 children and adolescents (65 males), of whom 73 (group 1, 52 males) were evaluated for short stature or growth retardation at age 3 to 15 years (median 11 years), with the following auxological characteristics: height $>2$ S.D. score below the mean for age or mid-parental height, height velocity below the 25 th percentile for age ( $>6$ months follow-up), and bone age delay $>2$ s.D. for age. Chronic systemic diseases, hyperprolactinemia and hypothyroidism (low thyroxine with or without hypothalamic thyrotropin-releasing hormone pattern were considered diagnostic) were ruled out before $\mathrm{GH}$ assessment. These patients underwent clonidine stimulation combined with the short-ACTH test, either the standard $(250 \mu \mathrm{g}$; $n=34)$ or the low $\left(1 \mu \mathrm{g} / 1.73 \mathrm{~m}^{2} ; n=39\right)$ dose. Fortytwo patients (32 males) in group 1 were primed with estrogen (ethynylestradiol $40 \mu \mathrm{g} / \mathrm{m}^{2} /$ day) for two days prior to testing (subgroup 1P) and 31 (20 males) were not primed (subgroup 1NP). These two group 1 subgroups were an outcome of our department's policy change regarding priming for GH testing (20). Patients who failed to achieve the cut-off growth hormone response on the first stimulation test underwent a repeated primed $\mathrm{GH}$ stimulation test, the $\mathrm{IIH}$ test (for those older than 4 years), or the glucagon test.

The control group (group 2) consisted of 42 healthy subjects (13 males) aged 6.9 to 17.5 years (median 12 years), who were referred to our Pediatric Endocrinology Clinic for evaluation of early or accelerated puberty or short stature due to premature closure of epiphyses, with no other evidence of pituitary or adrenal pathology. Subjects of this group underwent the short-ACTH stimulation test to rule out nonclassical 21-hydroxylase deficiency. Being that the 30-min 17-hydroxy-progesterone response is similar for the standard $250 \mu \mathrm{g}$ and the low-dose $1 \mu \mathrm{g}$ tests (17), we randomly assigned the patients to receive either $250 \mu \mathrm{g}(n=21)$ or $1 \mu \mathrm{g} / 1.73 \mathrm{~m}^{2}(n=21)$. Some of these data were used for control purposes in our previous study (19).

The study protocol was approved by the Ethics Committee of Rabin Medical Center, and informed consent was obtained from the patient and from the parents.

Table 1 Clinical data by group at time of testing

\begin{tabular}{|c|c|c|c|}
\hline & \multicolumn{2}{|c|}{$\begin{array}{c}\text { Group } 1 \text { (clonidine }-\mathrm{ACTH} \text { test) } \\
(n=73)\end{array}$} & \multirow[b]{2}{*}{$\begin{array}{c}\text { Group } 2 \\
\text { (ACTH only) }(n=42)\end{array}$} \\
\hline & $\begin{array}{l}\text { Subgroup 1NP } \\
\quad(n=31)\end{array}$ & $\begin{array}{l}\text { Subgroup 1P } \\
\quad(n=42)\end{array}$ & \\
\hline $\begin{array}{l}\text { Male/female }(n) \\
\text { Age (year) (mean } \pm \text { S.D.) }\end{array}$ & $\begin{array}{l}20 / 11 \\
9 \pm 3^{*}\end{array}$ & $\begin{array}{l}32 / 10 \\
12 \pm 2\end{array}$ & $\begin{array}{l}13 / 29 \\
12 \pm 3\end{array}$ \\
\hline $\begin{array}{l}\text { Pubertal stage } \\
\text { Prepubertal }(n) \\
\text { Tanner 2-3 }(n) \\
\text { Tanner 4-5 }(n)\end{array}$ & $\begin{array}{r}22 \\
9 \\
0\end{array}$ & $\begin{array}{r}22 \\
20 \\
0\end{array}$ & $\begin{array}{l}11 \\
17 \\
14\end{array}$ \\
\hline
\end{tabular}


Table 2 Growth hormone response to combined clonidine-short-ACTH test in 73 children of group 1. Results are mean \pm S.D.

\begin{tabular}{|c|c|c|c|c|c|c|}
\hline \multirow[b]{2}{*}{ GH response } & \multicolumn{2}{|c|}{$\begin{array}{l}\text { Subgroup 1NP } \\
(n=31)\end{array}$} & \multicolumn{2}{|c|}{$\begin{array}{c}\text { Subgroup 1P } \\
(n=42)\end{array}$} & \multicolumn{2}{|c|}{$\begin{array}{l}\text { Whole group } \\
\qquad(n=73)\end{array}$} \\
\hline & Peak GH (ng/ml) & $n$ & Peak GH (ng/ml) & $n$ & $n$ & $\%$ \\
\hline GH sufficient & $20.7 \pm 10.0$ & 30 & $18.6 \pm 7.5$ & 39 & 69 & 94.5 \\
\hline$<10 \mathrm{ng} / \mathrm{ml}$ in $1 \mathrm{st}$ test & $6.2 \pm 2.7$ & 5 & $6.7 \pm 1.5$ & 4 & 9 & 12.3 \\
\hline $\mathrm{GH}$ insufficient in 2 tests & 2.7 & 1 & $5.5 \pm 1.0$ & 3 & 4 & 5.5 \\
\hline False positive* & $4 / 30,13.3 \%$ & & $1 / 39,2.6 \%$ & & $5 / 69$ & 7.2 \\
\hline
\end{tabular}

Combined clonidine-short-ACTH test, oral clonidine $150 \mu \mathrm{g} / \mathrm{m}^{2}$ with i.v. ACTH $250 \mu \mathrm{g}(n=34)$ or $1 \mu \mathrm{g} / 1.73 \mathrm{~m}^{2}(n=39)$.

* Patients failed the first combined test and passed the second, primed, provocative test.

\section{Testing protocol}

All tests were carried out in the morning (0830$0900 \mathrm{~h}$ ) following an overnight fast and $30 \mathrm{~min}$ after an indwelling catheter was placed in a forearm vein for slow infusion of isotonic saline.

In the combined test group, a single oral dose of clonidine (Normopresan, Rafa, Jerusalem, Israel), $150 \mu \mathrm{g} / \mathrm{m}^{2}$, was administered simultaneously with an intravenous injection of ACTH (1-24) (Synacthen, Ciba-Geigy, Basel, Switzerland), either $250 \mu \mathrm{g}$ or $1 \mu \mathrm{g} /$ $1.73 \mathrm{~m}^{2}$. Blood samples were withdrawn at 0,30 and $60 \mathrm{~min}$ for cortisol determination and at 0,30 , 60, 90 and $120 \mathrm{~min}$ for $\mathrm{GH}$ determination. Pass levels were defined as a peak serum GH level of $10 \mathrm{ng} / \mathrm{ml}$ $(1,21)$, and a 30-min serum cortisol concentration of $520 \mathrm{nmol} / \mathrm{l}(19.4 \mu \mathrm{g} / \mathrm{dl})$ for the short-ACTH test (16).

The IIH test was performed with intravenous injection of short-acting human insulin, $0.1 \mathrm{U} / \mathrm{kg}$ body weight. Sampling for glucose levels was carried out every $15 \mathrm{~min}$, and for $\mathrm{GH}$ and cortisol every $30 \mathrm{~min}$, for $120 \mathrm{~min}$. The test was considered adequate for GH and HPA reserve assessment if hypoglycemia of $2.2 \mathrm{mmol} / \mathrm{l}(40 \mathrm{mg} / \mathrm{dl})$ or less was documented. The glucagon stimulation test was performed with an intramuscular injection of $30 \mu \mathrm{g} / \mathrm{kg}$, maximum $1 \mathrm{mg}$ glucagon (Novo Nordisk, Bagsvaerd, Denmark). Sampling for glucose, $\mathrm{GH}$ and cortisol levels was carried out every $30 \mathrm{~min}$ for $240 \mathrm{~min}$.

\section{Hormone assays}

Blood samples were immediately separated and kept frozen at $-20{ }^{\circ} \mathrm{C}$ until assayed. The serum cortisol and $\mathrm{GH}$ concentrations were determined with a commercially available solid phase chemiluminescent enzyme immunoassay employing an Immulite automated analyzer (DPC, Los Angeles, CA, USA). The detection limit was $28 \mathrm{nmol} / \mathrm{l}$ for cortisol and $0.05 \mathrm{ng} / \mathrm{ml}$ for $\mathrm{GH}$. The intra-assay and interassay coefficients of variation were, respectively, $9 \%$ and $10.3 \%$ with a cortisol level of $110 \mathrm{nmol} / \mathrm{l} ; 6.8 \%$ and $9.9 \%$ with a cortisol level of $640 \mathrm{nmol} / \mathrm{l} ; 3.7 \%$ and $3.8 \%$ with a GH level of $2.7 \mathrm{ng} / \mathrm{ml}$; and $4.0 \%$ and $3.3 \%$ with a $\mathrm{GH}$ level of
$12 \mathrm{ng} / \mathrm{ml}$. Serum glucose was measured by the GODPAP (Boehringer Manheim GmbH, Manheim, Germany) enzymatic colorimetric test on a Hitachi 717/911 device (Hitachi, Osaka, Japan) with typical interassay coefficients of variation of $0.7-3 \%$.

\section{Statistical analysis}

Within-group and between-group differences between the tests were assessed with analysis of variance (ANOVA); either pre-planned contrasts or Dunnet's test for subcomparisons to controls, were employed as appropriate. Statistical analyses were performed with the JMP software (SAS Institute, Cary, NC, USA) and Excel (Microsoft Corporation, Redmond, WA, USA).

\section{Results}

\section{Growth hormone response (Table 2)}

Nine of the 73 patients in group $1(12.3 \%)$ had an insufficient response of $\mathrm{GH}(<10 \mathrm{ng} / \mathrm{ml})$ on the first test, including 5 of the 31 non-primed patients (subgroup $1 \mathrm{NP})(16 \%)$ and 4 of the 42 primed patients (subgroup 1P) $(9.5 \%)$. Of the five nonprimed subjects (four males, three prepubertal, one pubertal stage 2 , and one prepubertal female) who failed the first test at 2.7, 5.5, 7.0, 7.6 and $8.9 \mathrm{ng} / \mathrm{ml}$, four passed the second (primed) test at 9.9, 10.1, 15.8 and $17.1 \mathrm{ng} / \mathrm{ml}$ and only one $(20 \%)$, a prepubertal male, also failed the second primed test, at $1.3 \mathrm{ng} / \mathrm{ml}$; he is currently being treated with $\mathrm{GH}$. Of the four primed subjects (one prepubertal male, two prepubertal females and one pubertal stage 2 female) who failed the first (primed) test at $4.8,6.4,7.4$ and $8.2 \mathrm{ng} / \mathrm{ml}$, three $(75 \%)$ also failed the second (primed) test, at 4.9, 5.0 and $6.7 \mathrm{ng} / \mathrm{ml}$, and only one, a prepubertal female, passed it at $20.2 \mathrm{ng} / \mathrm{ml}$. Considering that failure on two stimulation tests suggests a diagnosis of GH insufficiency, these figures indicate a rather low false-positive rate of $13.3 \%(4 / 30)$ for the nonprimed subjects and $2.6 \%$ (1/39) for the estrogen-primed subjects on the first stimulation test. The rate of GH deficiency/insufficiency 
Table 3 Cortisol levels $(\mathrm{nmol} / \mathrm{l})$ in short-ACTH test. Results are means \pm S.D.

\begin{tabular}{|c|c|c|c|c|c|c|}
\hline \multirow[b]{3}{*}{ Test } & \multicolumn{4}{|c|}{ Group $1(n=73)$} & \multirow{2}{*}{\multicolumn{2}{|c|}{$\begin{array}{c}\text { Group } 2(n=42) \\
\text { (ACTH only) }\end{array}$}} \\
\hline & \multicolumn{2}{|c|}{ Subgroup 1NP } & \multicolumn{2}{|c|}{ Subgroup 1P } & & \\
\hline & Cortisol & $n$ & Cortisol & $n$ & Cortisol & $n$ \\
\hline $\begin{array}{l}\text { Standard } 250 \mu \mathrm{g} \\
\text { 30-min response } \\
\text { Low dose }\end{array}$ & $799 \pm 214$ & 19 & $910 \pm 189$ & 15 & $725 \pm 170$ & 21 \\
\hline $\begin{array}{l}1 \mu \mathrm{g} / 1.73 \mathrm{~m}^{2} \\
30 \text {-min response }\end{array}$ & $728 \pm 161$ & 12 & $948 \pm 222$ & 27 & $656 \pm 112$ & 21 \\
\hline Total & & 31 & & 42 & & 42 \\
\hline $\begin{array}{l}\text { Basal }(0) \\
30-\text { min response } \\
30-\text { min }-0^{\star \star \star}\end{array}$ & $\begin{array}{l}450 \pm 205^{\star} \\
772 \pm 195 \\
321 \pm 176\end{array}$ & & $\begin{array}{l}604 \pm 230^{\star} \\
934 \pm 209^{\star \star} \\
330 \pm 200\end{array}$ & & $\begin{array}{l}337 \pm 130^{*} \\
690 \pm 145 \\
354 \pm 134\end{array}$ & \\
\hline
\end{tabular}

a 30 -min cortisol levels in the standard and low dose tests, within each group, were similar and were therefore considered together for each group.

${ }^{\star} P<0.05$ comparing all 3 groups; ${ }^{\star \star} P<0.05$ compared with subgroup 1 NP and group 2 ; ${ }^{\star \star *} P$ not significant for all 3 groups.

among the children with short stature (group 1) was $5.5 \%(4 / 73)$. Regarding the mean peak GH response, following exclusion of the 4 children with GH deficiency, values were similar for the nonprimed $(20.7 \pm$ $10 \mathrm{ng} / \mathrm{ml})$ and the primed subgroups $(18.6 \pm 7.5 \mathrm{ng} /$ $\mathrm{ml} ; P=0.32$ ) although there was no difference in their pubertal stage distribution (Table 1).

\section{Cortisol levels (Table 3)}

The mean 30-min serum cortisol level was similar for the standard and the low-dose tests in all three groups (subgroup $1 \mathrm{NP} 799 \pm 214 \mathrm{nmol} / \mathrm{l} \quad(n=19)$, $728 \pm 161 \mathrm{nmol} / \mathrm{l} \quad(n=12), \quad P=0.97 ;$ subgroup $1 \mathrm{P}$ $910 \pm 189 \mathrm{nmol} / \mathrm{l} \quad(n=15), \quad 948 \pm 222 \mathrm{nmol} / \mathrm{l} \quad(n=$ 27), $P=0.59$; group $2725 \pm 170 \mathrm{nmol} / \mathrm{l} \quad(n=21)$, $656 \pm 112 \mathrm{nmol} / \mathrm{l} \quad(n=21), \quad P=0.12$ respectively $)$. Therefore, the findings for the 30-min cortisol response in the $250 \mu \mathrm{g}$ and $1 \mu \mathrm{g} / 1.73 \mathrm{~m}^{2}$ stimulation tests within each group/subgroup were considered together.

The 30-min peak cortisol response in group 2 was $690 \pm 145 \mathrm{nmol} / \mathrm{l}$. Compared with group 2, subgroup $1 \mathrm{NP}$ had a similar mean 30-min peak cortisol response to the ACTH test $(772 \pm 195 \mathrm{nmol} / \mathrm{l}, \mathrm{P}=\mathrm{NS})$ whereas subgroup 1P patients showed a much higher response $(934 \pm 209 \mathrm{nmol} / \mathrm{l}, P<0.05)$. Comparisons of the basal cortisol levels between controls $(337 \pm 130 \mathrm{nmol} / \mathrm{l})$ and subgroup $1 \mathrm{NP}(450 \pm 205 \mathrm{nmol} / \mathrm{l})$, controls and subgroup $1 \mathrm{P}(604 \pm 230 \mathrm{nmol} / \mathrm{l})$ and subgroups $1 \mathrm{NP}$ and $1 \mathrm{P}$, all yielded a statistically significant difference $(P<0.05)$. However, delta cortisol levels (time $30 \mathrm{~min}-$ time 0 ) between the same groups were not significantly different (Table 3).

All group 1 children passed the standard test. One male patient $(1 / 39,2.6 \%)$ failed the $1 \mu \mathrm{g}$ test (peak cortisol response of $462 \mathrm{nmol} / \mathrm{l})$. His peak GH response was $16.8 \mathrm{ng} / \mathrm{ml}$, and his repeated $1 \mu \mathrm{g}$ test peaked at $514 \mathrm{nmol} / \mathrm{l}$.
In group 2, all patients who underwent the $250 \mu \mathrm{g}$ test $(n=21)$ showed HPA sufficiency. However, 2/21 $(9.5 \%)$ who underwent the low-dose test failed, with peak levels of 225 and $265 \mathrm{nmol} / \mathrm{l}$. Their repeated $1 \mu \mathrm{g}$ tests peaked at 753 and $603 \mathrm{nmol} / \mathrm{l}$ respectively.

The only side effect observed for the combined clonidine-ACTH test was drowsiness, which lasted for a few hours. Two male patients had syncope during urination following the test, without any sequelae. This has since been avoided by our asking parents to accompany the children to the toilet until the drowsiness resolves.

\section{Discussion}

The present study shows that the combined clonidineshort-ACTH test is a feasible tool for the simultaneous evaluation of the GH and HPA axes. The results for GH confirm the low false-positive rate and safety of the clonidine test described in previous studies of children (8-11). Using the now accepted cut-off value of $10 \mathrm{ng} / \mathrm{ml}$, only $12.3 \%(9 / 73)$ of our population had a below-threshold GH response on the first combined test, a failure rate that falls within the range documented in previous studies for clonidine stimulation alone: $23.2 \%(11)$ and $6 \%$ (9). Indeed, 4 of the 9 children who failed the first test failed the second one also (either the IIH or glucagon test); thus 5.5\% (4/73) of the shortstature children studied fulfilled the criteria for $\mathrm{GH}$ insufficiency/deficiency. As a result, the false-positive rate for the first combined stimulation test was actually only $7.2 \%(5 / 69)$, a figure similar to that found by Lanes and Hurtado (9) who performed the clonidine test only, and lower than that described for the glucagon test $(20 \%),(22)$ or the IIH test $(12-49 \%)(9,11)$ performed in normally growing children. We conclude that the addition of the ACTH test to the clonidine stimulation test does not influence the GH response. 
It should be noted that while clonidine provoked a strong $\mathrm{GH}$ response in children $(8-12)$, the various studies in adults have yielded contradictory results; Rahim et al. (7) found clonidine no better than placebo, whereas Grosman et al. (23) and Baranowska (24) reported a GH response similar to ours. Therefore, we refer our results to the pediatric age group.

In agreement with Marin et al. (20), we suggest that priming with sex steroids may reduce the falsepositive rate of the $\mathrm{GH}$ response to stimulation tests. Eighty-four percent of the nonprimed subjects had a $\mathrm{GH}$ response of $\geq 10 \mathrm{ng} / \mathrm{ml}$, compared with $90.5 \%$ of the primed subjects. Following exclusion of the patients who failed the second test too (thereby fulfilling the criteria for GH insufficiency), the false-positive rate was $13.3 \%$ for the nonprimed patients and only $2.6 \%$ for the primed patients. Marin et al. (20) showed a very high false-positive rate for prepubertal and pubertal stage $2(61 \%$ and $44 \%$ respectively), which decreased to zero in stages 4 and 5. Most of our combined test population (96\%) was either prepubertal or Tanner stage 2, and all our nonresponsive patients belonged to these two categories. Nevertheless, our failure rate for the nonprimed subjects was much lower - 3/22 (14\%) for the prepubertal patients and $1 / 7$ (14\%) for the patients in pubertal stage 2 - even though the other study used a lower cut-off point of $7 \mathrm{ng} / \mathrm{ml}$ and was conducted in a normally growing population. This large discrepancy might be explained by the different stimulation test used: exercise, arginine and insulin (20) have been found to be less reliable (with a higher false-positive rate) than clonidine (8-11) in children. Furthermore, the laboratory assay used in the earlier work to measure serum GH was a polyclonal RIA, whereas we employed the solid phase chemiluminescent enzyme immunoassay. The variation in GH assays can be as great as two- to threefold (25) among major reference laboratories, stressing again the need to standardize both the stimulation tests and the laboratory assays used for GH reserve assessment and measurement. From our results, we can conclude that the addition of the ACTH test to the clonidine stimulation test does not influence the GH response.

In light of the previous reports on cortisol level suppression by clonidine $(9,12)$, it is of interest that the peak cortisol value was higher in the combined-test subjects, indicating that clonidine does not interfere with the cortisol response to ACTH. Our results are in line with the studies of Milsom et al. (26) and Lyons et al. (27) showing that ACTH and cortisol responses to corticotropin-releasing hormone stimulation or to stress of surgery are not affected by the concomitant or pretreatment use of clonidine. Apparently clonidine, a central alpha-2-adrenergic agonist, by reducing peripheral sympathetic tone, and thereby lowering peripheral levels of noradrenaline (26), has a mild inhibitory effect on ACTH and cortisol secretion which is easily overcome by direct stimulation of the pituitary or adrenal glands.
In both groups, all subjects passed the $250 \mu \mathrm{g}$ test, and the failure rates for the low-dose ACTH test were also similar ( $2 \%$ for subgroup $1 \mathrm{NP}$ and $7 \%$ for group 2 ). In agreement with previous studies, the low-dose ACTH test, which provides more physiological adrenocortical stimulation (28), failed in a small proportion of children to detect an intact HPA axis $(18,29)$. Results concerning the better sensitivity of the low-dose than the standard-dose short-ACTH test to detect secondary adrenal insufficiency, when comparing them to the IIH test, have been contradictory $(18,29,30)$. These differences may be attributed to differences in dose, sampling time, cut-off level and studied population. Whether the $1 \mu \mathrm{g}$ dose is preferable remains uncertain. Should the low-dose test prove to be a more sensitive tool to detect partial or recent HPA insufficiency, the small decrease in specificity is an acceptable price.

Basal and peak cortisol responses were much higher in the patients primed with sex hormone; the increase was probably secondary to the estrogen-induced increase in cortisol-binding globulin levels. Brien (31) found that this effect occurs in both sexes and is demonstrable within 2 to 4 days. The delta cortisol response, however, was similar for all three groups. The post-priming elevation of both basal and peak cortisol levels raises the possibility that partial HPA insufficiency will be masked. Therefore, we primed five patients with known partial ACTH deficiency by previous IIH test (19), and none of them reached the pass cortisol level of $520 \mathrm{nmol} / \mathrm{l}$ (data not shown). Basal cortisol levels were also significantly higher in subgroup $1 \mathrm{NP}$ compared with group 2, while peak and delta levels were similar. This difference might be attributed to the younger age of subgroup $1 \mathrm{NP}$ and therefore higher stress at testing (Table 1).

The age at testing, the male/female ratio, and the pubertal stage distribution were different between the ACTH only and the combined-test groups. However, since serum cortisol levels do not correlate with either age or gender (32), we assume these differences are irrelevant to the results.

We conclude that the combined clonidine and shortACTH test is a reliable, safe and easy to perform tool for the simultaneous assessment of $\mathrm{GH}$ reserve and the integrity of the HPA axis in children with impaired growth. ACTH does not change the response of GH to clonidine, and clonidine does not interfere with the stimulation of cortisol by ACTH. Further studies of this combination are needed in children with pituitaryhypothalamic disease, in whom HPA insufficiency is more frequent.

\section{Acknowledgements}

The authors thank Mrs Gloria Ginzach and Mrs Charlotte Sachs of the Editorial Board, Rabin Medical Center, Beilinson Campus, and Oren Moran for their assistance. 


\section{References}

1 Tillmann V, Buckler JMH, Kibiridge MS, Price DA, Shalet JM, Wales YKH et al. Biochemical tests in the diagnosis of childhood growth hormone deficiency. Journal of Clinical Endocrinology and Metabolism 199782 531-535.

2 August GP, Lippe BM, Blethen SL, Rosenfeld RG, Seelig SA, Johanson AY et al. Growth hormone treatment in the United States: demographic and diagnostic features of 2331 children. Journal of Pediatrics 1990116 899-903.

3 Rona RJ \& Tanner JM. Aetiology of idiopathic growth hormone deficiency in England and Wales. Archives of Diseases of Childhood 197752 197-208.

4 Greenwood FC, Landon J \& Stamp TCB. The plasma sugar, free fatty acid, cortisol and growth hormone response to insulin in control subjects. Journal of Clinical Investigations 196645 437-449.

5 Vanderschueren-Lodeweyckx M, Wolter R, Malvaux P, Eggermont E \& Eeckels R. The glucagon stimulation test: effect on plasma growth hormone and on immunoreactive insulin, cortisol, and glucose in children. Journal of Pediatrics 197485 $182-187$.

6 Shah A, Stanhope R \& Matthew D. Hazards of pharmacological tests of growth hormone secretion in childhood. British Medical Journal 1992304 173-174.

7 Rahim A, Toogood AA \& Shalet SM. The assessment of growth hormone status in normal young adult males using a variety of provocative agents. Clinical Endocrinology 199645 557-562.

8 Gilad I, Topper E \& Laron Z. Oral clonidine as a growth hormone stimulation test. Lancet 1979 ii $278-280$.

9 Lanes R \& Hurtado E. Oral clonidine - an effective growth hormone-releasing agent in prepubertal subjects. Journal of Pediatrics $1982100710-714$.

10 Zadik Z, Chalew SA, Gilula Z \& Kowarsky A. Reproducibility of growth hormone testing procedures: a comparison between 24-h integrated concentration and pharmacological stimulation. Journal of Clinical Endocrinology and Metabolism 199071 $1127-1130$.

11 Ghigo E, Bellone J, Aimaretty G, Bellone S, Loche S, Cappa M et al. Reliability of provocative tests to assess growth hormone secretory status. Study in 472 normally growing children. Journal of Clinical Endocrinology and Metabolism 199681 3323-3327.

12 Laron Z, Gilad I, Topper E, Kaufman H \& Josefsberg Z. Low oral dose of clonidine: an effective screening test for growth hormone deficiency. Acta Pediatrica Scandinavia 198271 847-848.

13 Borst GC, Michenfelder HJ \& O'Briane JT. Discordant cortisol response to exogenous ACTH and insulin-induced hypoglycemia in patients with pituitary disease. New England Journal of Medicine 1982306 1301-1305.

14 Streeten DHP, Anderson GH \& Bonaventura MM. The potential for serious consequences from misinterpreting normal responses to the rapid adrenocorticotropin test. Journal of Clinical Endocrinology and Metabolism 19968 285-290.

15 Lindholm J \& Kehlet H. Reevaluation of the clinical value of the $30 \mathrm{~min}$ ACTH test in assessing the hypothalamic-pituitaryadrenocortical function. Clinical Endocrinology 198726 53-59.

16 Clayton RN. Short synacthen test versus insulin stress test for assessment of the hypothalamo-pituitary-adrenal axis: controversy revisited. Clinical Endocrinology 199644 147-149.

17 Dickstein G, Shechner C, Nicholson WE, Rosner I, Shen-Or Z, Adawai $\mathrm{F}$ et al. Adrenocorticotropin stimulation test: effects of basal cortisol level, time of day, and suggested new sensitive low dose test. Journal of Clinical Endocrinology and Metabolism 199172 $773-778$.

18 Tordjman K, Jaffe A, Grazas N, Apter C \& Stern N. The role of the low dose $(1 \mu \mathrm{cg})$ adrenocorticotropin test in the evaluation of patients with pituitary diseases. Journal of Clinical Endocrinology and Metabolism 199580 1301-1305.

19 Weintrob N, Sprecher E, Josefsberg Z, Weininger C, AurbachKlipper Y, Lazard D et al. Standard and low-dose short adrenocorticotropin test compared with insulin-induced hypoglycemia for assessment of the hypothalamic-pituitary-adrenal axis in children with idiopathic multiple pituitary hormone deficiencies. Journal of Clinical Endocrinology and Metabolism 199883 $88-92$.

20 Marin G, Domene HM, Barns KM, Blackwell BJ, Cassorla FG \& Cutler GB Jr. The effects of estrogen priming and puberty on the growth hormone response to standardized treadmill exercise and arginine-insulin in normal girls and boys. Journal of Clinical Endocrinology and Metabolism 199479 537-541.

21 Zadik Z, Chalew SA \& Kowarsky A. Assessment of growth hormone secretion in normal stature children using 24-h integrated concentration of $\mathrm{GH}$ and pharmacological stimulation. Journal of Clinical Endocrinology and Metabolism 199071 932-936.

22 Chanoine JP, Rebuffat E, Kahn A, Bergman P \& Vliet GV. Glucose, growth hormone, cortisol, and insulin responses to glucagon injection in normal infants, aged 0.5-12 months. Journal of Clinical Endocrinology and Metabolism 199580 3032-3035.

23 Grossman A. Weerasuriya K, Al-Damluji S, Turner P \& Besser GM. Alpha 2-adrenoceptor agonists stimulate growth hormone secretion but have no acute effects on plasma cortisol under basal conditions. Hormone Research 198725 65-71.

24 Baranowska B. The effect of clonidine on pituitary hormone secretion in physiological and pathological states. Journal of Cardiovascular Pharmacology 198710 (Suppl 12) S235-S239.

25 Rakover Y, Masala R, Issam T \& Wener E. The clinical significance of GH provocative test results: comparison between four different growth hormone immunoassays. Hormonal Research 199850 (Suppl 3) 56 (abstract 130).

26 Milsom SR, Donald RA, Espiner EA, Nicholls MG \& Livesey JH. The effect of peripheral catecholamine concentrations on the pituitary-adrenal response to corticotrophin releasing factor in man. Clinical Endocrinology 198625 241-246.

27 Lyons FM, Bew S, Sheeran P \& Hall GM. Effect of clonidine on the pituitary hormonal response to pelvic surgery. British Journal of Anaesthesiology 199778 134-137.

28 Oelkers W. Dose-response aspects in the clinical assessment of the hypothalamo-pituitary-adrenal axis, and the low-dose adrenocorticotropin test. European Journal of Endocrinology 1996 $13527-33$.

29 Mayenknecht J, Diederich S, Bahr V, Plockinger U \& Oelkers W. Comparison of low and high dose corticotropin stimulation tests in patients with pituitary disease. Journal of Clinical Endocrinology and Metabolism 199883 1558-1562.

30 Abdu TAM, Elhadd TA, Neary R \& Clayton RN. Comparison of the low dose short synacthen test $(1 \mu \mathrm{g})$, the conventional dose short synacthen test $(250 \mu \mathrm{g})$, and the insulin tolerance test for assessment of the hypothalamo-pituitary-adrenal axis in patients with pituitary disease. Journal of Clinical Endocrinology and Metabolism $199984838-843$.

31 Brien TG. Human corticosteroid-binding globulin. Clinical Endocrinology 198114 193-212.

32 Knutsson U, Dhalgren J, Marcus C, Roberg S, Bronnegrad M, Stierna P \& Albertsson-Wikland K. Circadian cortisol rhythms in healthy boys and girls: relationship with age, growth, body composition, and pubertal development. Journal of Clinical Endocrinology and Metabolism 199782 536-540.

Received 11 August 1999

Accepted 17 March 2000 